\title{
Minisett Nursery Techniques in Cassava (Manihot esculenta Crantz): A Review
}

\author{
K. T. Sruthy ${ }^{1 *}$ and G. Rajasree ${ }^{1}$
}

Department of Agronomy, College of Agriculture, Vellayani, Thiruvananthapuram-695 522, Kerala, India

*Corresponding author

\begin{tabular}{l} 
K e y w o r d s \\
$\begin{array}{l}\text { Minisett nursery } \\
\text { techniques, } \\
\text { Conventional } \\
\text { planting, Cassava }\end{array}$ \\
\hline Article Info \\
\hline $\begin{array}{l}\text { Accepted: } \\
\text { 20 February } 2020 \\
\text { Available Online: } \\
\text { 10 March } 2020\end{array}$ \\
\hline
\end{tabular}

\section{Introduction}

The minisett technique is a good option for rapid multiplication of cassava planting materials for the production of rooted cuttings especially for the contingent planting in aberrant rainfall conditions and uncertainty in the rain fall pattern. The aberrant weather conditions makes the rainfed cultivation of cassava risky due to poor seedling establishment on account of drying of setts.
Under such conditions where the crop growing period is short, cassava can be cultivated by nursery planting. In conventional planting method of cassava, 10 to 12 noded setts are used while in minisett propagation, one, two or three noded cuttings are used as planting material and multiplication ratio by this method is 1:60 against normal sett planting 1:10 (KAU, 2016). 
Rapid multiplication of cassava using minisetts in comparison with normal sett planting

George and Nedunchezhiyan (2008) reported that stem yield $\left(\right.$ no.ha $\left.^{-1}\right)$ in cassava was 24,000 in normal sett planting, while in minisett technique it was 60,000 . They also reported an increased yield of $80 \mathrm{t} \mathrm{ha}^{-1}$ for minisett cassava wherein the normal sett planting produced an yield of only $30 \mathrm{t} \mathrm{ha}^{-1}$. Isaac et al., (2015) studied the initial growth habits and yield of different tropical tuber crops under minisett cultivation and compared it with conventional planting in grow bags under homestead situation. In cassava, germination was found to be earlier in minisetts than normal setts but further growth was slow and vegetative mass put forth was lower in minisetts. In this experiment though the early growth of was slow in minisetts, it progressed later. The tuber yields in all the tuber crops were generally higher with conventional planting material than the minisetts. However the authors concluded that from the perspective of commercial farming, minisett technology is advantageous as smaller planting materials require lesser spacing and this when coupled with higher plant density would lead to comparable yields as to that of normal planting materials.

According to IITA (2001), one or two node hardwood minisetts, four to six node semi mature minisetts and six to ten nodes tip shoot minisetts were successful in rapid multiplication of cassava which resulted about 60-100 ministem cuttings from a cassava plant. Raising tissue culture cassava seedlings in plastic cups filled with different potting media has been tried for hardening purpose and there exists ample scope to explore the possibility of raising cassava minisetts in plastic cups or containers to reduce the cost in nursery and for easy transportation to the main field. Planting rooted plantlets of tissue culture cassava having $4-5 \mathrm{~cm}$ length in plastic cups with perforations at bottom, filled with potting mixture and keeping them for one month period for hardening has been reported to be an effective method of acclimatisation by Shiji et al., (2014). The Central Tuber Crops Research Institute (CTCRI) has developed a rapid multiplication technique using cassava minisetts in which two- node cuttings are raised in the nursery in shade house (35 per cent shade). The minisetts are planted end to end horizontally, $5 \mathrm{~cm}$ deep leaving $5 \mathrm{~cm}$ between the rows. The minisetts are transplanted to the main field 3 to 4 weeks after planting at a spacing of 45 x $45 \mathrm{~cm}$ (George and Nedunchezhiyan, 2008). However maximum root damage has been reported during uprooting the seedlings from cassava nurseries (Nedunchezhiyan et al., 2008). The percentage of adoption in case of cassava nursery raising has also been found to be low (Rani and Murugan, 2011) probably due to high cost of production and seedling damage on transplanting. The success of growing cassava minisetts in protrays is evident from the investigations carried out in Kerala Agricultural University by Vipitha (2016).

\section{Factors influencing minisett seedlings performance}

There are characteristic differences among the nursery media in providing the required conducive environment for sprouting of minisetts. The number of nodes of minisetts at planting is an important factor physiologically deciding the cassava tuber yield in main field. Age at which cassava seedlings are transplanted to the main field is another factor to be investigated as transplanting over aged seedlings can cause root damage, while transplanting the seedlings at an early stage may result in poor establishment in the main field. Many of the factors of production of cassava seedlings in nursery like length of 
stem or number of nodes at planting can influence the dry matter accumulation at the end of tuberisation and thus yield performance of the crop in the main field.

The length of the sett or number nodes per sett is an important factor affecting the field establishment and total dry matter production in minisett cassava. According to Alves (2002), the shoot and root growth in cassava upto 30 Days After Planting depend on food reserves in the stem. George (2006) reported that the two node and three node cassava minisetts had higher establishment percentage of 86.94 and 88.68 respectively compared to single node minisett (76.79 per cent). The root spread and dry matter production were also found to be higher in three node cuttings. In an investigation conducted in Kerala Agricultural University, Isaac et al., (2011) reported that the per plant tuber yield obtained by planting two noded cassava minisetts was comparable to that obtained with normal sett planting. In another study on cassava, Bridgemohan and Ronell (2014) found that two node minisetts produced higher tuber yield at harvest compared to 1,3 or 4 node minisetts.

The performance of seedlings in the nursery varies with the potting mixture used in the nursery. Jata et al., (2013) evaluated different nursery techniques in cassava and found that maximum shoot length was observed in plants grown in compost alone or in combination with sand and soil in dapog nursery method. In a study conducted in Kerala Agricultural University, Isaac et al., (2013) reported that the sprouting percentage and speed of emergence of Diascorea minisetts were significantly higher when soil alone was used as a potting medium compared to soil less media. The effect of addition of different compost to the nursery potting media was studied in other crops also. According to Prasanth et al., (2014), addition of vermi compost in potting mixture increased the organic matter content, phosphorus, magnesium, iron, manganese and zinc availability when potting mixture was prepared by mixing coir pith compost and vermi compost in 3:1 ratio for raising pepper seedlings in protrays. While standardising the growth medium based on thermo chemical digest, Jayakrishna et al., (2016) reported that, highest fruit yield was obtained in chilli when thermo chemical digest, coir pith compost and soil were given in 1:2:1 proportion in potting medium. Vermi compost could be considered as a commercial potting medium owing to its physical and chemical properties which support the better establishment and growth of seedlings. When potting medium was substituted with vermi compost, significantly higher shoot growth was recorded in tomato seedlings than those in the soil medium (Atiyeh et al., 2000). Normal top soil as a potting medium for nursery raising has been explored by several researchers. Abudulai and Quansah (2002) reported that normal top soil is an ideal medium for growing yam minisetts and 78-92 per cent sprouting of minisetts from Diascoria alata was observed when top soil was mixed with saw dust as a potting medium.

The transplanting age of the seedling is likely to have an influence on its establishment in the main field. According to Tetteh et al., (1997), the age of transplanting significantly influenced the establishment percentage and survival rate in seed propagated cassava which were found to be highest with transplanting at 41 DAS (Days After Sowing) compared to 27,34 or 48 DAS. Marked variation in root length of cassava seedlings was reported in dapog nursery with different age of seedlings and increasing the age of seedlings in nursery led to lesser establishment in main field due to more transplanting shock (Jata et al., 2013). Age of 
seedling decides the seedling quality which is one of the factors deciding the yield of the transplanted crop. According to Tetteh et al., (1997), the age of transplanting significantly influenced the tuber yield in seed propagated cassava and tuber yield ranged from $6525 \mathrm{~kg}$ $\mathrm{ha}^{-1}$ for the 27 days old seedlings to $17764 \mathrm{~kg}$ $\mathrm{ha}^{-1}$ for the 41 days old seedlings.

In conclusion, from the above mentioned review it is concluded that there is ample scope for minisett nursery technique in cassava and it is a good option for the quality rapid multiplication of planting material. The scientific studies comparing the field performance of minisett cassava and normal set planting are meagre and hence need to be validated in the field to fine tune the minisett technology for better adoption by farming community.

\section{References}

Abudulai, M. and Quansah, C. 2002. Alternative media to sawdust for minisett propagation of seed yam (Dioscoria spp.). Trop. Sci. 42:47-51.

Alves, A. A. C. 2002. Cassava botany and physiology. In: Hillocks, R. J., Thresh, J. M. and Bellotty, A. C. (eds.), Cassava- Biology, Production and Utilization. CABI Publishing, U.K, pp.67-89.

Atiyeh, R.M., Subler, S., Edwards, C.A., Bachman, G., Metzger, J.D., and Shuster, W. 2000. Effects of vermicomposts and composts on plant growth in horticultural container media and soil. Pedo biol. 44: 579-590.

Bridgemohan, P. and Ronell, S. H. B. 2014. Effect of initial stem nodal cutting strength on dry matter production and accumulation in cassava (Manihot esculenta Crantz). J Plant Breed. Crop Sci. 6(6): 64-72.

George, J. 2006. Quality planting material production in tuber crops. In: Proceedings of the $14^{\text {th }}$ Triennial Symposium of ISRTC, 20-26, November 2006, Trivandrum, $315 \mathrm{p}$.

George, J. and Nedunchezhiyan, M. 2008. Rapid production techniques in tuber crops. In: Nedunchezhiyan, M.(ed.), Advance Techniques in Quality Planting Material Production and Commercial Cultivation of Tropical Tuber Crops, Regional Centre, Central Tuber Crops Research Institute, Bhubaneswar, Orissa, pp. 70-78.

IITA[International Institute of Tropical Agriculture]. 2001. Rapid Multiplication of Cassava. International Institute of Tropical Agriculture, Nigeria. 63p.

Isaac, S. R., Dickson, V. J., and Varghese J. 2015. Evaluation of minisetts as planting material for homestead cultivation of tuber crops. Indian $J$. Agric. Allied Sci. 1(4): 7-10.

Isaac, S. R., Podikunju, B., and Pillai, S. P. 2011. Evaluation of minisetts as planting materials in cassava [abstract]. In: Abstracts, National Seminar on Climate Change and Food Security: Challenges and Opportunities for Tuber Crops; 20-22, January, 2011, Thiruvananthapuram. Indian Society for Root Crops, Thiruvananthapuram, Kerala, p.137. Abstract No. PWNM/P7.

Isaac, S. R., Varghese, J., Remya, N., and Krishnan, A. 2013. Influence of nursery media and mulching on sprouting and growth of Greater Yam (Dioscorea alata) minisetts. J. Root Crops. 39(2): 247-249.

Jata, S. K., Lenka, A., and Nedunchezhiyan, M. 2013. Evaluation of different nursery techniques in cassava (Manihot esculenta Crantz). J. Root Crops. 30(2): 238-241.

Jayakrishna, J., Thampatti, M. K. C., and Leno, N. 2016. Standardisation of 
growth medium based on thermo chemical digest produced from degradable solid waste by rapid conversion technology. Int. J. Appl. Pure Sci. Agri. 2(10): 76-80.

KAU [Kerala Agricultural University]. 2016. Package of Practices Recommendations: Crops (15 ${ }^{\text {th }}$ Ed.). Kerala Agricultural University, Thrissur, 392p.

Nedunchezhiyan, M., George, J., and Byju, G. 2008. Nursery techniques in tuber crops. In: Nedunchezhiyan, M(ed.), Advance Techniques in Quality Planting Material Production and Commercial Cultivation of Tropical Tuber Crops, Regional Centre, Central Tuber Crops Research Institute, Bhubaneswar, India, pp. 66-78.

Prasath, D., Vinitha, K. B., Srinivasan, V., Kandiannan, K., and M. Anantharaj. 2014. Standardisation of soil-less nursery mixture for black pepper (Piper nigrum L.) multiplication using plug trays. J. Spices Arom. Crops. 23(1): 1-9.

Rani, J. A. and Murugan, P. P. 2011. Yield maximisation of cassava through the adoption of recommended technologies in Tamil Nadu [abstract]. In: Abstracts, National Seminar on Climate Change and Food Security: Challenges and Opportunities for Tuber Crops; 20-22, January, 2011, Thiruvananthapuram. Indian Society for Root Crops, Thiruvananthapuram, Kerala, p.137. Abstract No. PTD/01.

Shiji, R., George, J., Sunitha, S., and Muthuraj, R. 2014. Micropropagation for rapid multiplication of planting materials in cassava (Manihot esculenta Crantz). J. Root Crops 40(1): 23-30.

Tetteh, J. P., Omenyo, E. L., and Dankwa, A. 1997.Tuberisation and effect of age of seedlings at transplant on yield of seed propagated cassava. Ghana J. Agric. Sci. 30(1): 9-14.

Vipitha, V. P. 2016. Agronomic interventions for a sustainable rice based cropping system in paddy fields. Ph.D thesis, Kerala Agricultural University, Thrissur, 228p.

\section{How to cite this article:}

Sruthy, K. T. and Rajasree, G. 2020. Minisett Nursery Techniques in Cassava (Manihot esculenta Crantz): A Review. Int.J.Curr.Microbiol.App.Sci. 9(03): 2731-2735.

doi: https://doi.org/10.20546/ijcmas.2020.903.312 